I P6S54

NMAI 



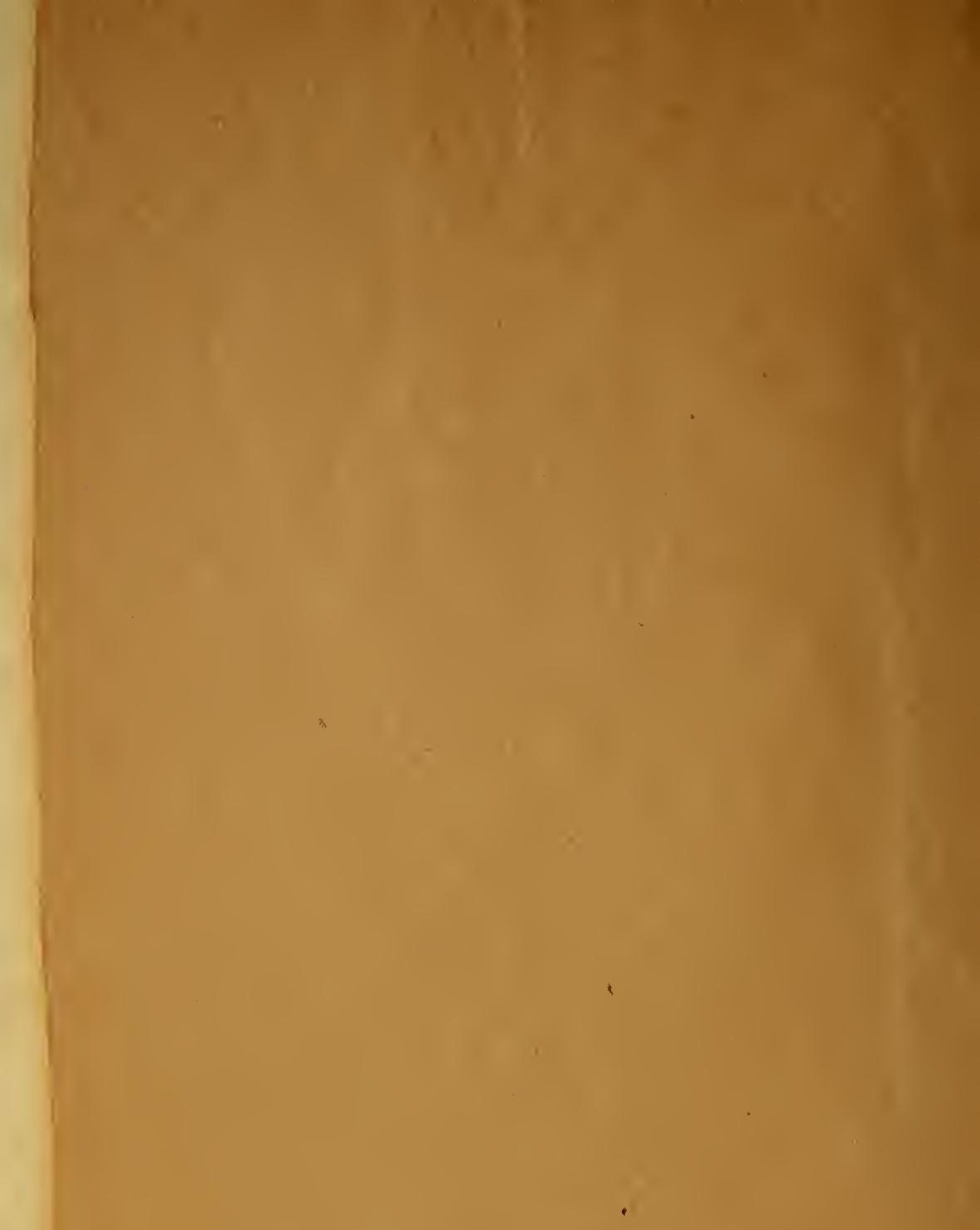




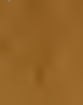

$1: 3$ 
gorve ăd * * the Gllaty * *
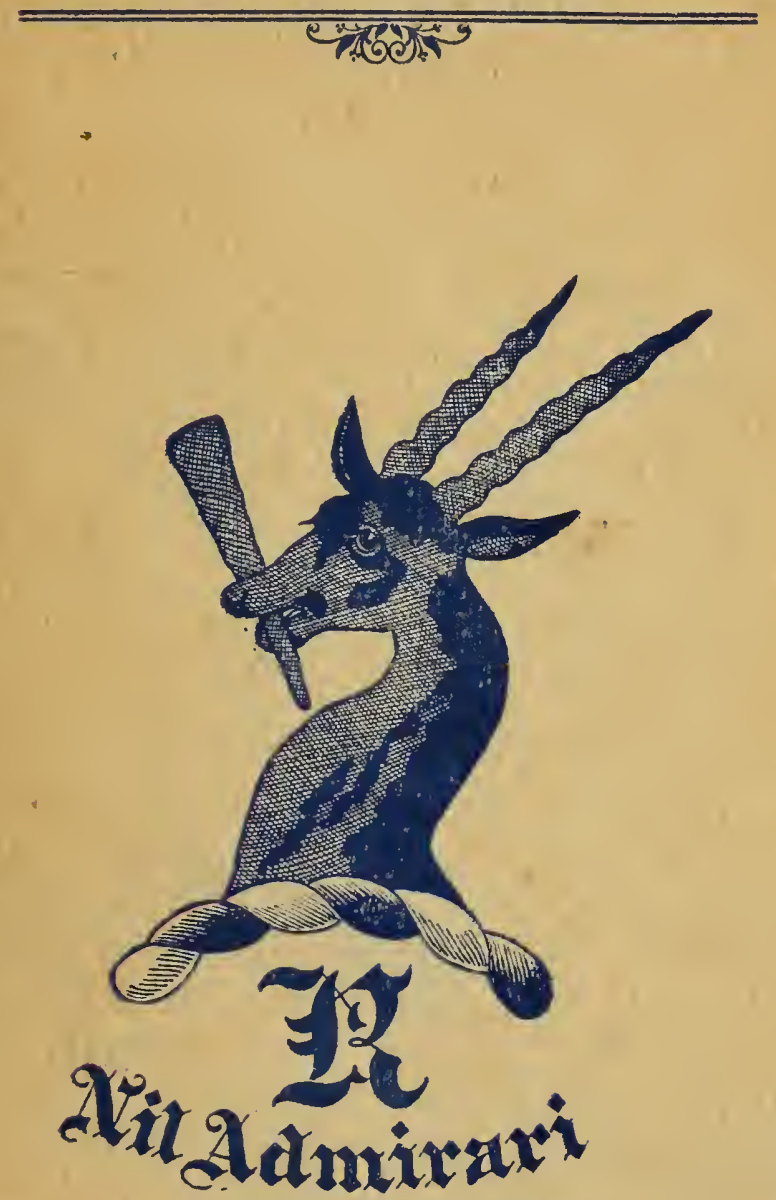

By Catherine Randolph Sheets

F.

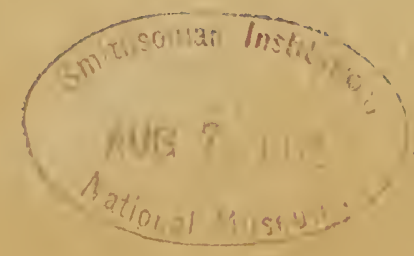





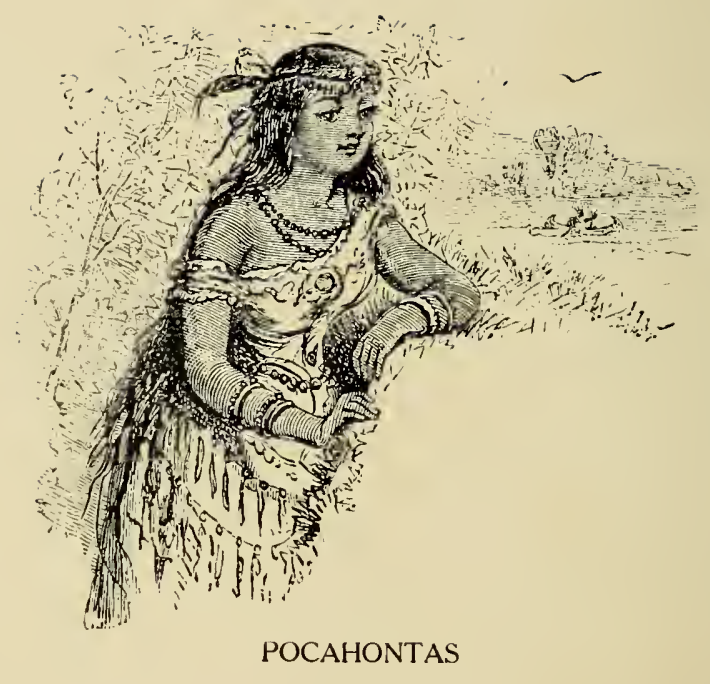




\section{LOVE WILL FIND THE WAY}

The Marriage of

JOHN ROLFE

AND

POCAHONTAS

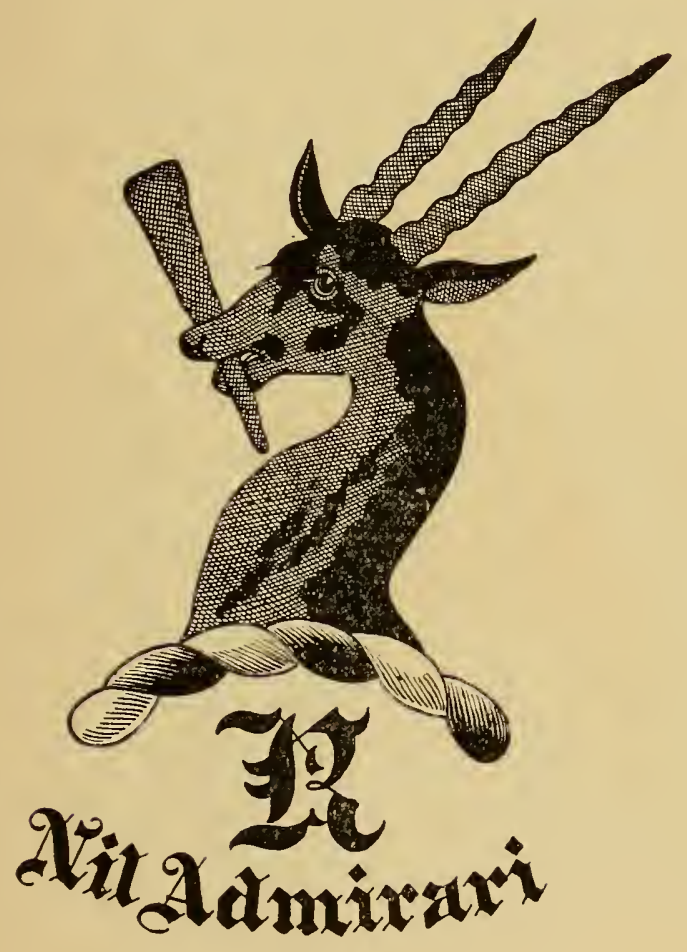

By Catherine Randolph Sheets

His Letter containing the reasons moving him thereunto

$\leftrightarrow x$

PRESS OF GIBSON BRothERS

WASHINETON, D. C.

(C) AUG 7

1229649

-iiriaritan 


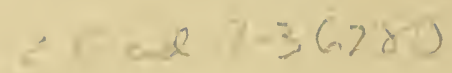

Copyright 1907, by Catherine RaNDOLPH Sheets 


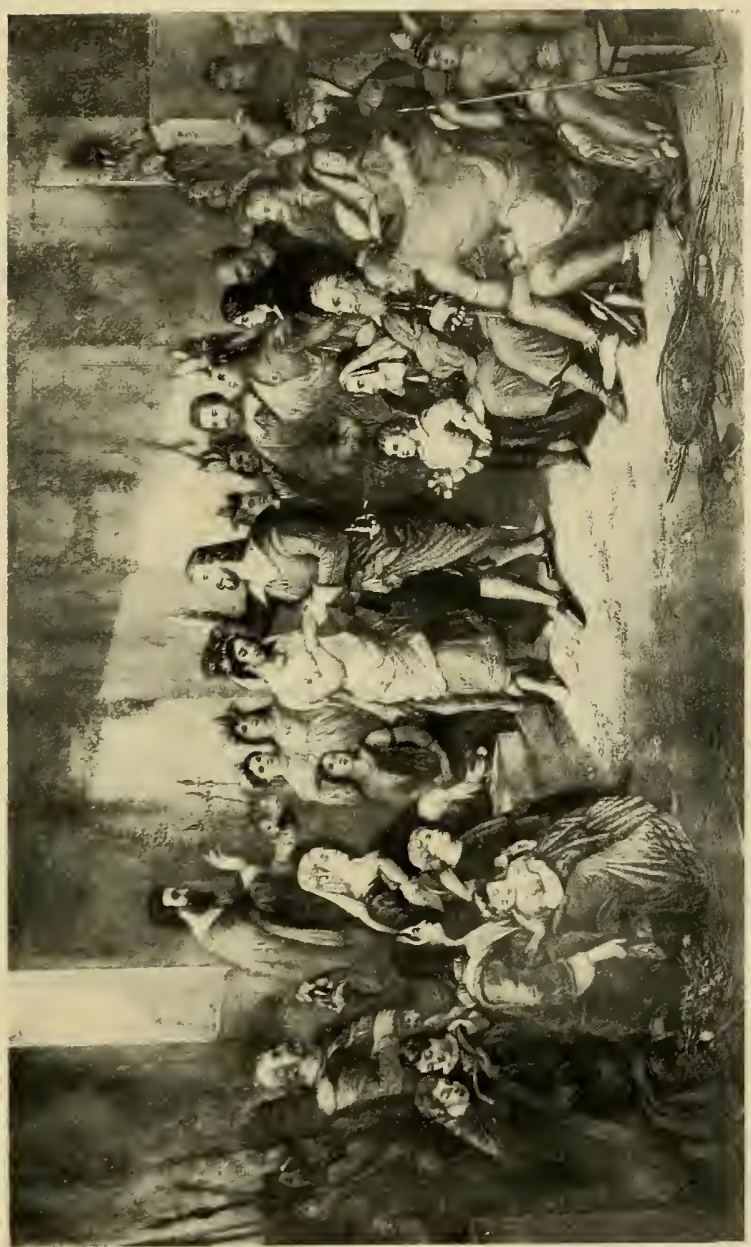

"Matoaka, alias Rebecca Filia Pontentics. Ponic. Powhatani Imp. Virginiri," and beneath. "Matoax, alias Rebecka, daughter of the (Mighty Princ Powhatan), emperor of Altanough kor nouch, alias Virginiri," converted and baptised in the Christian faith, and WIFE TO THE, worshipful Mr. John Rolfe, Ae. 2 г, a 1616." (Sec Second Series vii, Emen. 307.

Portrait engraved by Simon de Passe.

"The Virginia woman, whose picture I sent rou, died this last week at Gravesend, below Greenwich, as she was returning homeward." 


\section{A TUDOR LOVE SONG.}

"Love will find the way."

"Over the mountains

And over the waves,

Under the fountains

And under the graves;

Under floods that are deepest, Which Neptune obey;

Over rocks that are steepest;

Love will find out the way.

When there is no place

For the glow-worm to lie;

When there is no space

For receipt of a fly;

Where the ostrich does not venture, I,est herself fast she lay;

If love come, he will enter And soon find his way.

You may esteem him

A child for his might;

Or you may deem him

A coward for his flight;

But if she, whom love doth honour,

Be concealed from the day,

Set a thousand guards upon her--

Love will find out the way.

Some think to lose him

By having him confined;

And some do suppose him,

Poor thing! to be blind.

But if ne'er so close you wall him

Do the best that you may;

Blind love, if so you call him,

Will find out his way.

For you may train the eagle

To stoop to your feet;

Or you may inveigle

The Phoenix of the East;

The lioness, you may move her

To give o'er her prey;

But you will never stop a lover-

He will find out his way." 
"March 2I-I6I6-Rebecca Wrolfe wyffe of Thomas Wrolfe gent," in one of the Church Registers.

"In the Parish Register, Gravesend, is the following-

I6r6-May 2-Rebecca Wrothe entry wyffe of Thomas Wrothe gent."

"A Virginia lady bons here, was buried in ye chancel-"

"Notes and Queries-Vol. v, p. I 23, 3rd Series.

March 29, I6I7 (Birch's, Court and Times of James Ist, ii, v, 3 p.

"During the year I 622 Rolfe died, leaving a wife and children, besides the child he had by Pocahontas."

See statement appearing in the books of the Company under date of 1622 .

These most astounding church registers, in the light of revealed documents, can the better be explained by a close scrutiny of the lives and acts of John Rolfe's immediate family, namely, "Rolfe" or "Wrolffe," which, reading between the lines of the letter, goes without saying; concerning the subsequent serious opposition in the rights of John's heir, history is replete, and but repeats itself, in this most admirable and "worshipful Mr. Iohn Rolfe" the only husband of Pocahontas.

This letter is of value not only as a family letter, but as a matter of State interest; and on both sides of the sea, the little twelve-year-old child bespoke peace and love in an act that should forever have sealed the bond between England and America. We may well ponder the prediction of Rolfe as a child of promise and the development of God's promises in the history of this race, of representative men of to-day in State and pulpit:- "And their works do follow them."

"Love, the all-comprehending virtue, is the bed-rock of true moral character, and the specific virtues are the out-croppings from the underrunning rock. Love is the root of the tree and gratitude, justice, mercy, self-denial, humility, faith, are the branches and the fruit." 
"Let us in life and death

Thy steadfast truth declare,

And publish with our latest breath

Thy love and guardian care."

"[The coppy of the gentleman's letter to Sir Thomas Dale, that after married Powhatan's daughter, con-

taining the reasons moving him thereunto.]"

Honorable Sir, and most worthy Governor:

When your leisure shall best serve you to peruse these lines, I trust in God, the beginning, will not strike you into a greater admiration, than the end will give you content. It is a matter of no small moment concerning my own particular which here I impart unto you, and which toucheth me so nearly, as the tenderness of my salvation. Howbeit I freely subject myself to your grave and mature judgement, deliberation, approbation and determination, assuring myself of your zealous admonitions, and Godly comfort, either persuading me to desist, or encouraging me to persist therein, with a religious fear and godly care, for which (from the very instant, that this began to root itself, within the secret bosom of my breast) my daily and earnest prayers have been, still are, and ever shall be produced forthwith as sincere, a godly zeal, as I possibly may, to be directed aided and goverened in all my thoughts, words and deeds, to the glory of God, and for my eternal consolation. To persevere wherein I never had more need, nor (till now) could even imagine to have been moved, with the like occasion.

But (my case standing as it doth) what better wordly refuge can I here seek, than to shelter myself under the safety of your 
favorable protection? And did not my case proceed from an unspotted conscience, I should not dare to offer to your views and approved judgement these passions of my troubled soul, so full of fear and trembling is hypocracy and dissimulation.

But knowing my own innocency, and Godly fervour, in the whole prosecution thereof, I doubt not of your benign acceptance, and element construction. As for malicious depravers, and turbulent spirits, to whom nothing is tasteful, but what pleaseth their unsavory pallet, I pass not for them, being well assured in my persuasion (by the often trial and proving of myself, in my holiest meditations and prayers) that I am called hereunto by the spirit of God, and it shall be sufficient for me to be protected by yourself in all virtuous and pious endeavors. And for my more happy proceeding herein, my daily oblations shall ever be addressed to bring to pass so good effects, that yourself, and all the world may truly say:- "This is the work of God, and it is marvelous in our eyes."

But to avoid tedious preambles, and to come nearer the matter: first suffer me with your patience, to secure peace and make clear the way wherein $I$ walk, from all suspicions and doubts, which may be concerened therein, and faithfully to reveal unto you, what should move me hereunto.

Let therefore this my well advised protestation, which here I make between God 
and my own conscience, be a sufficient witness, at the dreadful day of judgement (when the secret of all men's hearts shall be opened) to condemn me herein, of my chiefest intent and purpose be not, to strive with all my power of body and mind in the undertaking of so mighty a matter, no way led (so far forth as man's weakness may permit) with the unbridled desire of carnal affection: but for the good of this plantation, for the honour of our creation, for the glory of God, for my own salvation, and for the converting to the true knowledge of God and Jesus Christ, an unbelieving creature, namely

\section{POCAHONTAS}

To whom my hearty and best thoughts are, and have a long time been so intangled, and inthralled in so intricate a laborinth that I was even awearied to unwind myself thereat.

But Almighty God, who never faileth His, that truly invoke His Holy name, hath opened the gate, and led me by the hand that I might plainly see and discern the safe paths wherein to tread.

To you therefore, (most noble Sir) the patron and father of us in this Country do I utter the effects of this my settled and long continued affection (which hath made a mighty war in my meditations) and here I do truly relate, to what issue this dangerous combat is come unto, wherein I have not only examined, but thoroughly 
tried and pared my thoughts even to the quick, before I could find any fit wholesome and apt application to cure so dangerous an ulcer: I never faileth to offer my daily and faithful prayers to God, for His sacred and holy assistance. I forgot not to set before mine eyes the frailty of mankind, his proneness to evil, his indulgence of wicked thoughts, with many other imperfections, wherein man is daily engrossed, and oftentimes overthrown, and them compared to my present estate. Nor was I ignorant of the hearty displeasure which Almighty God conceived against the sons of Levi and Israel for marrying strange wives, nor of the inconvenience which may thereby arise, with other the like good motives which made me look about warily and with good circumspection into the grounds and principal agitation, which thus should provoke me to be in love with one whose education hath been rude, her manners barbarous, her generation accursed, and so discrepant in all nurtriture from myself, that oftentimes with fear and trembling, I lave ended my private controversie with this: surely these are wicked instigations, hatched by him who seeketh and delighteth in man's destruction; and so with fervent prayers to be ever preserved from such diabolical assaults (as I took those to be) I have taken some rest.

Thus when I had thought I had obtained my peace and quietness, behold another, 
but more gracious tentation hath made breeches into my holiest and strongest meditations with which I have been put to a new trial, in a straighter manner than the former: for besides the many passions and sufferings, which I have daily, hourly, yea and in my sleep endured, even awakening me to astonishment, taxing me with remissness, and carelessness, refusing and neglecting to perform the duty of a good christian, pulling me by the ear, and crying: "Why dost not thou endeavor to make her a christian?"

And these have happened to my great wonder, even when she hath been furtherest separated from me, which in common reason (were it not an undoubted work of God) might breed forgetfulness of a far more worthy creature. Besides, I say the holy spirit of God hath often demanded of me, why I was created? If not for transitory pleasures and worldly vanities, but to labour in the Lord's Vinyard, there to sow and plant, to nourish and increase the fruits thereof, daily adding with the good husbandman in, the gosple, somewhat to the talent, that in the end the fruits may be reapped, to the comfort of the laborer in this life, and his salvation in the world to come? And if this be, as undoubtedly this is, the service Jesus Christ requireth of his best servants woe unto him that hath these instruments of pity put into his hands, and wilfully despiseth to work 
with them. Likewise, adding hereunto her great appearance of love to me, her desire to be taught and instructed in the knowledge of God, her capableness of understanding, her aptness and willingness to receive any good impression, and also the spiritual, besides her own incitesments stirring me up hereunto.

What should I do? Shall I be of so untoward a disposition, as to refuse to lead the blind into the right way? Shall I be so unnatural, as not to give bread to the hungry? or uncharitable, as not to cover the naked? Shall I despise to actuate these pious duties as a christian? Shall the base fear of displeasing the world, overpower and with-hold me from revealing unto man these spiritual works of the Lord, which in my meditations and prayers, I have daily made known unto Him?

God forbid. I assuredly trust $\mathrm{He}$ hath thus dealt with me for my eternal felicity, and for His Glory: and I hope to be guided by His Heavenly Grace, that in the end by my faithful pains, and christian labour, I shall attain to that blessed promise, pronounced by that Holy Prophet Daniel, "unto the Righteous that bring many unto the knowledge of God. Namely, that they shall shine like the stars forever and ever."

A sweeter comfort cannot be to a true Christian, nor a greater encouragement for him to labour all of the days of his life, in the performance thereof, nor a greater 
gain of consolation, to be desired at the hour of death, and in the day of judgement.

Again, by my reading, and conference with honest and religious persons, have I received no small encouragement, besides serene my conscience, the clearness of my conscience, clean from the filth of impurity, quae est inster muri ahenci, which is unto me a brazen wall.

If I should set down at large, the perturbations and Godly motives, which have stirred within me, I should but make a tedious and unnecessary volume. But I doubt not these shall be sufficient both to certify you of my true intents, in discharging of my duty to God, and to yourself, to whose gracious providence I humbly submit myself, for his glory, your honor, and Country's good, the benefit of this plantation, and for the converting of one unregenerate, to regeneration; which I beseech God to grant, for his dear Son Christ Jesus sake.

Now if the vulger sort, who square all man's actions, by the base rule of their own filthiness, shall tax or taunt me in this my godly labour; let them know, my hungry appetite, to gorge myself with incontinency; sure (if I would, and were so sensually inclined) I might satisfy such desire, though not without a seared conscience, yet with Christians more pleasing to the eye, and less fearful in the offence unlawfully committed. 
Nor am I in so desperate an estate, that I regard not what becometh of me; nor am I out of hope but one day to see my Country, nor so void of friends, nor mean in birth, but there to obtain a match to my great content: nor have I ignorantly passed over my hopes there, or regardlessly seek to lose the love of my friends, by taking this course: I know them all, and have not rashly overstepped any.

But that it please God thus to dispose of me (which I earnestly desire to fulfill my ends before set down) I will heartily accept of it as a godly tax appointed me, and I will never cease, (God assisting me) until I have accomplished, and brought to perfection so holy a work in which I will daily pray God to bless me, to mine, and her Eternal happiness.

And thus desiring no longer to live, to enjoy the blessings of God, then: this my resolution doth tend to such godly ends, not doubting of your favorable acceptance, I take my leave, beseeching Almighty God to rain down upon you, such plentitude of his heavenly graces, as your heart can wish and desire, and so I rest,

At your command most willing to be disposed of

IOHN ROLFE.

Virginia therefore standing now in such goodly proportions, and fair forwardness of thriving, as it was never yet hither to been in, since it began to be first 
planted; cannot but soon come to perfection, to the exceeding great comfort of all well affected Christians, and no small profit of the planters and adventurers: if it be well seconded and supplied, with a good number of able men: Wherefore, let none be hereafter unwilling all they may to further this most honorable action, and be forward to uphold and support it from falling, by their speech, and countenance, and freely adventuring thither, both in their persons, as God hath enabled them. To conclude, as Azariah said once to King Azah, IUDAH, and Benjamin, so say I unto all. Be ye strong therefore, and let not your hands be weak: for your work shall have a reward. And as the holy Apostle said to the Corinthians "Be ye therefore steadfast, unmoveable, abundant always in the works of the Lord, for as much as ye know your labour is not in vain in the Lord, let us not therefore be weary of well doing: for in due season we shall reap, if we faint not:" as the Apostles told the Galations. Farewell.

Finis. affairs in

Virginia to June I8-

I 6 I 4 . 





Gaylord Syrocuse, N. Y.

Stockion, Colif. 
SMITHSONIAN INSTITUTION LIBRARIES

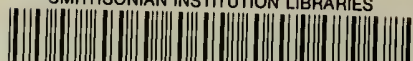

|||||||||||||||||||||||||||||||||||||||||||||||||||||||||||||||||||||

39088008007171 